\section{Цитування:}

Дунсюань У. Романс в китайській музиці «періоду відкритості»: від Romance - до Kunstlied і художньої пісні. Вісник Національної академії керівних кадрів культури $і$ мистецтв : наук. журнал. 2021. № 1. С. 192-197.

Dongxuan Wu. (2021). Romance in Chinese music of the open period: from Romance to Kunstlied and artistic song. National Academy of Culture and Arts Management Herald: Science journal, 1, 192-197 [in English].

\author{
Dongxuan Wu, \\ graduate student, senior lecturer \\ of the Belarusian State Academy of Music \\ senior lecturer of the Hanshan Normal university \\ ORCID: https://orcid.org/0000-0002-2973-9816 \\ dxwu80@hotmail.com
}

\title{
ROMANCE IN CHINESE MUSIC OF THE OPEN PERIOD: FROM ROMANCE TO KUNSTLIED AND ARTISTIC SONG
}

The purpose of the article is to identify ways to form and develop the national Chinese art song "period of openness". The article reveals the ideas of the origin of the national romantic musical and poetic genre, features of the German Kunstlied, Chinese romance in the "period of openness" (from Romance to Kunstlied and artistic song). The interaction of traditional Chinese and Western European music systems, in which pentatonics are organically combined with classical-romantic harmony and uniform accentuation, is studied. The research methodology involves the application of a systematic approach, as well as methods of analytical, comparative, art, using which on the examples of Chinese art song "openness period" (composers Luo Zhongzhong, Li Inha, Lu Tsai-i) analyzes the process of assimilation of national traditions in chamber and vocal creativity of Chinese composers, which found expression in the accentuation of articulatory and phonetic features of the pronunciation of the verbal text, the folk throat manner of singing, the interpretation of the voice as a color paint. The regional specificity of Chinese romance is considered on the example of the songs "Returning to Mount Qingshan" by Zhang Lizhong, "You will like it" by Shi Xin. The scientific novelty of the work is to identify transformational changes in Chinese music of the twentieth century. based on the peculiarities of the refraction of European new compositional techniques (dodecaphony, serialism), which is reflected in the romances of Chinese composers "New Wave" or "national Chinese musical avant-garde" (Luo Zhongzhong, Chen Mingzhu, Zhu Jianyer). Conclusions. The study found that the "period of openness" for China was a time of reform and change in all spheres of life, including the art of music. The basis for the creation of a national romantic musical and poetic genre was the German Kunstlied, whose principles were in tune with the aesthetic foundations of classical Chinese art. Changes in creative concepts in Chinese music based on musicians' awareness of the possibility of a subjective approach to art. Their figurative and semantic kinship became the key to the formation and approval of the national-genre foundations of Chinese artistic song. The ways of spreading and popularizing Chinese art song in the context of the idea of the festival-competition movement are also determined.

Keywords: romance; Chinese art song; Art members; national traditions; "China's period of openness."

Дунсюань У, аспірант, старший викладач Білоруської державної академія музики, старший викладач Інституту музики Ханьшаньского педагогічного університету

Романс в китайській музиці «періоду відкритості»: від Romance - до Kunstlied і художньої пісні

Мета статті - виявлення шляхів формування і розвитку національної китайської художньої пісні «періоду відкритості». У статті розкриваються ідеї зародження національного романтичного музично-поетичного жанру, особливості німецької Kunstlied, китайського романсу в «період відкритості» (від Romance до Kunstlied i художньої пісні). Вивчається взаємодія традиційної китайської і західноєвропейської музичних систем, в яких органічно поєднуються пентатоніка 3 класико-романтичною гармонією $\mathrm{i}$ рівномірною акцентуацією. Методологія дослідження передбачає застосування системного підходу, а також методів аналітичного, компаративного, мистецтвознавчого, за допомоги яких на прикладах китайської художньої пісні «періоду відкритості» (композитори Ло Чжунжун, Лі Інха, Лу Цзай-і) аналізується процес асиміляції національних традицій в камерно-вокальній творчості китайських композиторів, що знайшло вияв у акцентуації артикуляційних і фонетичних особливостей вимови вербального тексту, народної горлової манери співу, трактування голосу як колористичної фарби. Розглядається регіональна специфіка китайського романсу на прикладі пісень «Повертаючись до гори Ціншань» Чжан Лічжун, «Тобі це сподобається» Ши Синя. Наукова новизна роботи полягає у виявленні трансформаційних змін у китайській музиці XX ст. на основі особливостей заломлення європейських нових композиційних технік (додекафонія, серіалізм), що знайшло відображення в романсах китайських композиторів «Нової хвилі» або «національного китайського музичного авангарду» (Ло Чжунжун, Чень Мінчжу, Чжу Цзяньєр). Висновки. В результаті проведеного дослідження встановлено, що «період відкритості» для Китаю став часом реформ і змін у всіх сферах життя, в тому числі і музичному мистецтві. Основою створення національного романтичного музично-поетичного жанру стала німецька Kunstlied, принципи якої виявилися співзвучними естетичним основам класичного мистецтва Китаю. Зміни 


\section{Вісник Національної академії керівних кадрів культури і мистецтв № 1’2021}

творчих концепцій в китайській музиці на грунті усвідомлення музикантами можливості суб'єктивного підходу до мистецтва. Їх образно-смислова спорідненість стала запорукою формування та затвердження національножанрових основ китайської художньої пісні. Також визначаються шляхи поширення і популяризації китайської художньої пісні в контексті ідеї фестивально-конкурсного руху.

Ключові слова: романс; китайська художня пісня; Kunstlied; національні традиції; «період відкритості Китаю».

Relevance of the topic. The rapprochement of Eastern and Western civilizations, which began in the middle of the XXI century, led to the appearance of the so-called "New music" in the musical culture of China as a result of the interaction of Western and Eastern types of thinking, borrowed and traditional style traditions, manifested in the novelty of artistic and aesthetic norms and properties. The policy of reforms and opening up of China led to the rapid development of Chinese musical academic art, as a result of which its locality was overcome and was set outside the country while noting the beginning of the "period of openness" (from 1976 to the present). Chamber vocal music was no exception: after the end of the "cultural revolution," the revival of the art song - the Chinese romance begins.

Research analysis. The controversy around the genre of romance and the terminology associated with it has been going on as long as the genre itself exists. The controversy surrounding this literary and musical phenomenon is caused by the diversity of the romance, the variety of its content and forms. The line between the genre definition of romance and song is often blurred and not defined. Studies devoted to the genres of chamber vocal music cover a wide problem field, including the issues of musical aesthetics, genre classification and shaping, the interaction of speech and musical intonation, the principles of musical drama $[3,4]$.

The understanding of the specifics and ways of interaction between the musical thinking of the East and the West is a core interest in science [1]. The works of Chinese musicologists and composers are devoted to the study of the national specifics of Chinese chamber vocal lyrics $[3,9$, 10]. In terms of the mentioned studies, attention is drawn to the emphasis on the problem of terminology [3, 4, 7], the aesthetic features of Chinese art song $[8,9]$, the study of the Chinese traditional modal system [5], the manifestation of the musical style of the XX century in the romances of Chinese composers [6, 10]. Some analytical essays on the romances of Chinese composers are contained in the studies of $\mathrm{Cao}$ Shuli [10], Kaiyuan Day [2], Yan Jianan [12], Tszyu Qihong [8], etc.

At the same time, one of the urgent tasks of modern musicology is the creation of a panoramic picture of the existence of a modern romance within the dialectical relationship of the traditional and the new by disclosing the range of composer searches of the late XX - early XXI century.

The purpose of the article is to identify ways of formation and development of the national Chinese art song of the "period of openness."

Presentation of the main material. The concept of "romance" ("romance" in Spanish) arose in the XV-XVI centuries in Spain and was used concerning a poetic composition in Spanish (belonging to the group of Romance) language, in contrast to verses in Latin, which were adopted in church use and chants. The difference from Latin poems was also in the content side: consequently, being predominantly secular, the romances had an epic and lyric-dramatic character, thematically related to historical events, depicting disasters, wars, or exploits of legendary heroes. ${ }^{1}$

The first examples of musical romances properly belong to the early Renaissance. At the early stage of the genre's formation, the musical properties were subordinate to the poetic ones: for example, the form - stanza without a refrain (chorus) - was dictated by the form and rhythm of the poetic work. The performers were also not principled (often they were not indicated at all), frequently they were dictated by the singers and instrumental musicians (vocal ensemble) who turned up at the court at a particular moment. A distinctive feature of the early romance can be considered a developed polyphonic texture polyphonic or homophonic-polyphonic (example $1)$.

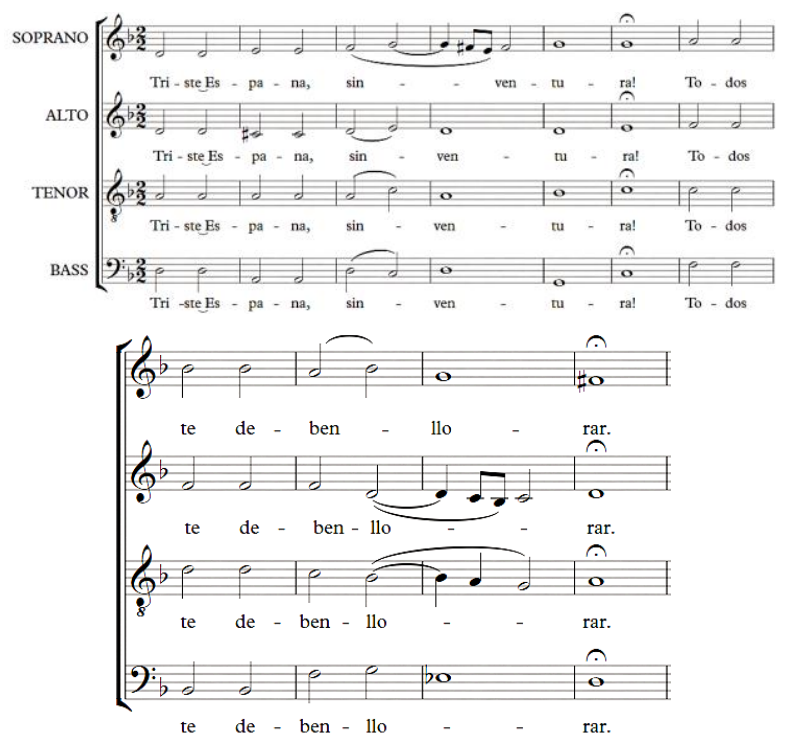

Music sample 1. Juan del Ensina. Romance "Triste España sin ventura." 
Romances, as a rule, were combined into collections, ${ }^{2}$ thanks to which we have an idea not only of the status of this genre in the musical culture of the Spanish aristocracy of the XV-XVI centuries but also of the names of composers.

Gradually, the romance took on the form of a vocal melody performed by one singer or singer, accompanied by a guitar or vihuela (a popular instrument in Spain of that time). This democratization of the composition of the performers allows the romance to gain more and more popularity. ${ }^{3}$ Thus, compositions of this genre are included not only in collections but also in schools of play. The musical form also undergoes significant modifications - during a particular period, a refrain and variational development of the instrumental accompaniment part appear; the subject is also expanding significantly.

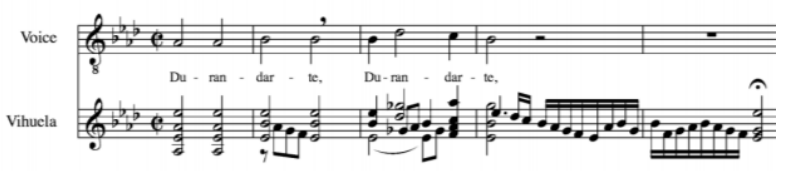

Note sample 2. Luis de Milan. Romance "Durandarte, durandarte."

The popularity of the genre brought the romance beyond the borders of Spain, and in other countries, it was immediately perceived as a musical (and not literary) vocal work of a lyrical nature for a voice accompanied by an instrument or ensemble, orchestra. ${ }^{4}$

At the same time, a special phenomenon in the musical art of the XVIII century - the subtext of melodies of popular dances (mainly minuets and sicilianas) - can be considered the direct predecessor of the romance in its modern sense. Hence, to the already existing musical compositions with a clear beautiful melody, the text was added, which was often created specifically for a particular composition, while the melody of the vocal part duplicated the instrumental one. Quite often, such subtext was amateur, but it could also belong to professional composers 5 while receiving the name "aria."

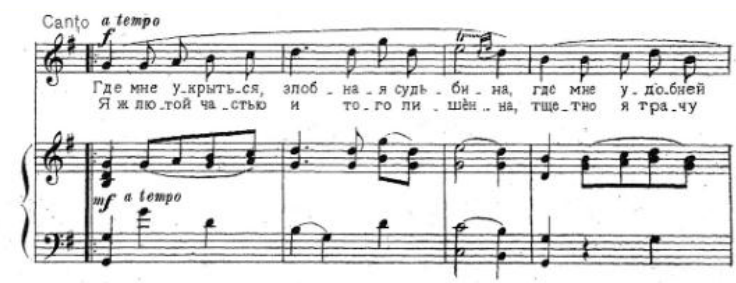

Note sample 3. G. Teplov.

"Idleness Between Work." №1 Minuet (Menuetto alternativo)

Although in such early examples of romance it is obvious the composers' desire to reflect not only the form of the stanza but also to create a musical embodiment adequate to poetry, they were still far from complete emotional adherence to the poetic image in the melodies of songs.

The active development of romance began in the second half of the XVIII century in combination with the intensification of amateur music-making. In the works of composers from different countries, ${ }^{6}$ In the works of composers from different countries, an approach is gradually crystallizing, uniting the text and musical components into a single musical and poetic fabric. Thus, for example, in the Austro-German culture, an independent genre of solo song with instrumental accompaniment Lied is formed, originating from the first examples of Minnesang art of the late Middle Ages and the Renaissance. Here is an example of a song for voice with piano accompaniment by V.A. Mozart, which, on the one hand, stylistically approaches his opera arias, on the other hand, within the in form and intimate expression corresponds to the genre of romance:

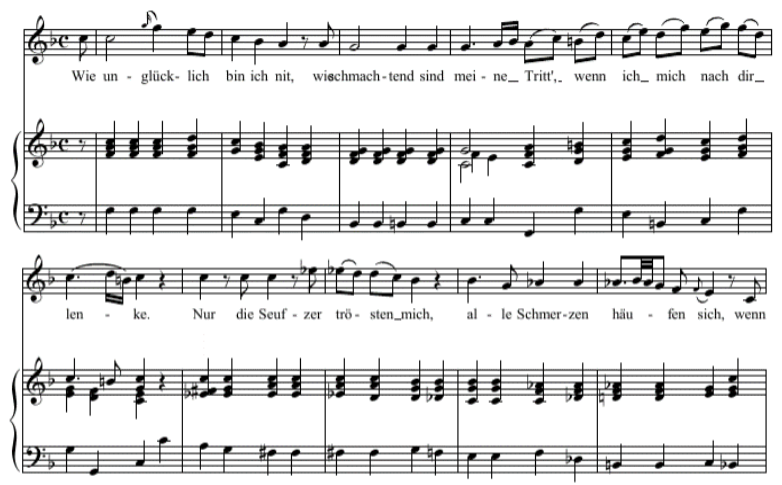

\section{Note sample 4. V.A. Mozart. \\ Lied fur eine Singstimme. \\ Mit Klavier begleitung "Wie unglucklich bin ich nit," KV 147 (125)}

In the first half of the XIX century, Lied became one of the leading poetic genres, pushing aside odes, hymns and "the poetry of reflections" Reflexionsgedichte, largely thanks to the work of the Austro-German poets of the Romantic era, and first, I. Goethe and G. Heine.

The highest achievement of composers in the field of Lied was a lively musical and poetic intonation, unique in each work while coming from the embodiment of the imagery of the verse. The brightest examples of Austro-German romance art are demonstrated by the works of $\mathrm{L}$. Beethoven, F. Schubert, R. Schumann, J. Brahms, H. Wolf, etc.

F. Schubert's work turned out to be the key to the formation of the phenomenon of romantic songs not only in Austro-German music but also in Western European musical culture in general. Moreover, by having chosen the Austro-German romance tradition as a stylistic reference point, Chinese composers laid the foundation for their national tradition, embodied in the artistic song.

The combination of traditional Chinese and Western European musical systems has led to the 


\section{Вісник Національної академії керівних кадрів культури і мистецтв № 1’2021}

creation of works that are unique in terms of expressive structure, in which pentatonic scale is organically combined with classical-romantic harmony and uniform accentuation. The period of 1920-40 ${ }^{7}$, became fundamentally important for the development of Chinese chamber-vocal lyricism of the Western-type when there is an active development of classical-romantic harmony and the richest genre diversity accumulated by Western European music by the XX century.

Having lost the leadership of mass song in the 1950s, experienced all the blows of the "cultural revolution," art song was revived only after 1976, when composers again paid close attention to this genre, as a result of which, from an artistic point of view, quite strong opuses began to appear. ${ }^{8}$

The activation in the 1980s of professional composers, primarily Luo Zhongzhong, Li Yinghai, Lu Tszai-i, in chamber vocal genres led to the expansion of the ideological and figurative content of the art song, to the search for new concepts and techniques, and also stimulated concert performance.

During the "period of openness" in Chinese musical art, there is a turn towards national origins. Thus, for example, there is a revival of ancient Chinese music and philosophy, in particular, the philosophical understanding of the categories "static" and "emptiness". Composer Qu Xiaosong rightly notes that Chinese traditional music has "a psychological sense of time, which is static; in Chinese music, there is a state of detachment, which is distinguished by the depth of the image. What is static? You look at the mountains, at the stars, and do not think that they are moving. On the contrary, they inspire a sense of something mysterious - just because of their static nature" [12, p. 63]. For example, the art songs "The Light of the Stars in the Forests" by Qian Tongmin, "The Fog of Today's Night" by Ao Changchun, "Night Rain by the Xiangjiang River" by Zhu Shizhui.

The return to national origins was also manifested in the understanding of the voice as a special timbre. For example, Chinese composers began to accentuate the articulatory and phonetic features of the pronunciation of verbal text and the throaty folk manner of singing, to use the voice as part of instruments. However, if in Western music experiments with the voice began already at the beginning of the XX century, being actively implemented in vocal opuses of the second avantgarde and minimalism ${ }^{9}$, then in Chinese chamber vocal music, the interpretation of the voice as a coloristic paint became possible only in the 1980s. A vivid example of the use of the folk singing style $^{10}$ can be found in Luo Zhongrong's "Trusting Han Chuo of Yangzhou" (from the "Autumn Melodies" cycle). ${ }^{11}$
It is widely known that China is a multinational state, therefore, while embodying national traditions in the genre of art songs, it is important to preserve the stylistic differences inherent in the country's national regions. For example, Zhang Lizhong's "Returning to Mount Qingshan" song is based on the musical material of the traditional song of the peoples of the northwest, "Believe the Heaven on the Road," and characteristic elements of the Qinghai song "Flowers" are used in the melody of the song "You Will Like It" by Shi Xin.

While searching for national identity in the complex modern sound world, Chinese composers have found themselves in demand for a serial "non-national" in nature - composition system that obeys universal numerical laws. Due to historical circumstances, the immersion of Chinese composers in the avant-garde art of the XX century took place decades after its emergence, as if postfactum. Only in the "period of openness" it became possible not only to study the musical heritage of the classics of the XX century (B. Bartok, I. Stravinsky), opuses of representatives of the Novovensk school (A. Schoenberg, A. Webern, A. Berg), post-war avant-garde and serialism, but also the adaptation of Western experience by following a natural path from imitation to the original implementation of the achievements of world musical art in the own work $^{12}$. In musicology, this new cultural phenomenon has received the name "national Chinese musical avant-garde" [6] or "New Wave" [7].

The first musician to turn to dodecaphony in his works was Luo Zhongrong, whose romance "Cross the River for the Lotus" 13 was the first serial work published in China. It is important to note that the appearance of this miniature prompted Chinese musicians to experiment in this direction. Chen Mingzhi and Zhu Jian'er are among the most significant names.

The turn of the XX - XXI centuries was marked by the flourishing of Chinese romanticism in the art of music by bringing forward a whole galaxy of highly professional composers, among whom the leading place rightfully belongs to one of the most famous Chinese composers of our time, Lu Zai-i. As the composer himself noted, his vocal opuses are "directly related to the genre of artistic songs, romantic in spirit" [8, p. 4]. For example, in his song "Homesickness," Europeanromantic romance traditions are refracted: the musicality of the poetic text, the image of singing and song, the theme of love for the Motherland, resolved in a metaphorical, symbolic way (example 5). 

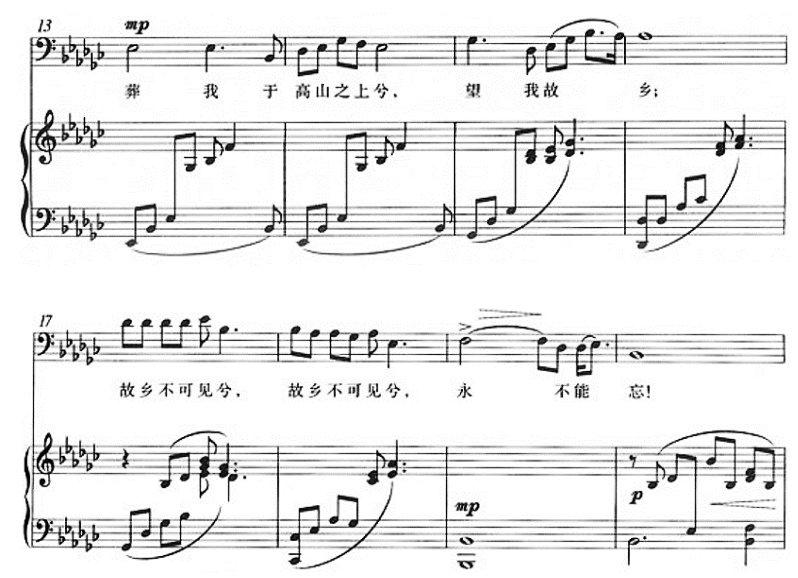

\section{Note sample 5. Lu Zai-i. Art song "Homesickness" 14}

In general, the development of the romanceart song genre, the growth of its popularity lead not only to the activation of the composer's creativity. The growing popularity of romance leads to the development of the festival and competition movement in China. We highlight the Ningbo International Vocal Competition ${ }^{15}$ among the most significant projects, which is held every three years, and The Chinese Golden Bell Award For Music ${ }^{16}$ - a national competition without international participation, which is held every two years. The television broadcasting factor also contributes to the attraction of professionals and a wide audience of chamber vocal music lovers to the romance genre.

Conclusions. Thus, the "period of opening" for China has become a time of reforms and changes in all spheres of life, including the art of music. A symbol of the change in creative concepts in music was the realization by Chinese musicians of the possibility of a subjective approach to art.

The basis for the creation of a national romantic musical-poetic genre was the German Kunstlied, the principles of which turned out to be consonant with the aesthetic foundations of classical Chinese art. Their figurative and semantic commonality became the key to the formation and approval of the national genre foundations of Chinese art song.

\section{Примімки}

${ }^{1}$ Western literary scholars often draw analogies between the genre of Spanish romance and the ballad popular in other countries.

${ }^{2}$ For example, "The Palace Songbook" contains poetry and music from about 40 Spanish romances, most of which are anonymous. Some songwriters included romances by the best Spanish composers of the time, including Juan del Encina (1469-1529), Francisco de Peñalosa (c. 1470-1528), Francisco Millan (c. 1500-?), Juan de Anchieta (c. 1462- 1523), etc.

${ }^{3}$ Among the most famous composers of romances of this period were Luis de Milan (c. 1500-c. 1561),
Luis de Narvaez (1490-1547), Alonso Mudarra (15101580), Juan Bermudo (1510-1565).

${ }^{4}$ For more details on the national characteristics of the genre in German, French, Russian, Belarusian, and Chinese music, see our article "Romance genre in Western and Chinese music: interactions and analogies" [3].

For example, J. Sperontesi and G. Teplov. Under the pseudonym, Sperontesi published his works Johann Sigismund Scholze (1705-1750) - German musician, composer, and poet. Among the many dances for instrumental performance, the most famous "vocal" minuet is "The Muse Singing on the Place River." Grigory Nikolaevich Teplov (1711-1770) - a major dignitary at the courts of Elizabeth and Catherine, amateur musician, violinist, harpsichordist, and composer. Teplov is the author of the first printed collection of Russian romances "Idleness Between Work."

6 The most prominent romance composers in Germany are C.F.E. Bach (1714-1788), F. Benda (1709-1786), who belonged to the "Berlin school"; in France - E.N. Megul (1763-1817), A.M. Burton (17671844) in Russia - F.M. Dubyansky (1760-1796) and O.A. Kozlovsky (1757-1831). Probably, it was the achievements of these composers that allowed the romance schools to develop in the era of romanticism in the previously mentioned countries.

During this period, a whole galaxy of highly professional composers emerged - Huang Qiy, Qing Zhui, ZhaoYuanren, Xiao Yumei, Jiang Dingxiang, etc.

8 Among them are "Where are you" by Shi Guangnan, "If I were a goose" by Qin Yongcheng, "Memories in My Heart" by Shi Wangchun, "Sequoia Tree" by Shen Chuangsin, "Spring of Science" by Shan Deyi, "Clear Memories "Zhu Xianara," The Bridge" by Lu Zaiy-i.

${ }^{9}$ For example, E. Igotti writes about singing and speech methods of sound production which connecting folklore tradition and modern music by citing the names of such composers as D. Ligeti, L. Berio, D. Cage, S. Slonimsky, B. Tishchenko, as well as the composer and performers M. Monk who were using unusual methods of sound production and "the relative tone and duration of the sound" [4].

${ }^{10}$ It should be carried in mind that some Chinese musicologists mistakenly classify folk songs as art songs (for example, Ding Shande and Li Yinghai). In terms of the accompaniment of the piano, the mentioned songs received a new life, but the particular fact does not change the issue that they remain folk, not artistic: they are characterized by folk speech, their music is not distinguished by "sublimity."

${ }^{11}$ In vols. 27-44, the composer introduces inserted exclamations “噢” (“ehu!"), Which should be performed in a folk manner.

${ }^{12}$ A similar phenomenon was typical for the period of the "Thaw" in the USSR.

${ }^{13}$ For more details about this romance, see our article "The genre of romance in the Chinese musical tradition: musical and historical ways of development." [3].

14 The romance "Homesickness" was honored with the highest award of contemporary Chinese vocal music, the "Golden Bell" in 2003.

15 For example, 369 singers from 17 countries took part in the 2018 competition. 


\section{Вісник Національної академії керівних кадрів культури і мистецтв № 1’2021}

16 The Golden Bell competition has already been held 12 times. Since 2011, performers from Hong Kong, Macau, and Taiwan have taken part in the competition. The Music Prize is awarded in four categories: composition, performance, theoretical work, and personal achievement in the art of music. For example, 270 people took part in the 2019 competition. In total, 42 top-level competitive events were held in the areas of "vocals" (ethnic, bel canto) and "instrumental performance" (violin, erhu).

\section{Лimepamypa}

1. Алкон, Е. Музыкальное мышление Востока и Запада, континуальное и дискретное : автореф. дис. ... д-ра искусствовед. : спец. 17.00 .02 - муз. Искусство. Владивосток, 2001. 40 с.

2. День Кайюань. Вокальные миниатюры Чжу Цзяньэра: жанрово-стилистические черты. Проблеми взаємодії мистецтва, педагогіки та теорії і практики. 2017. Вип. №47. С. 223-236.

3. Дунсюань У. Жанр романса в китайской музыкальной традиции: музыкально-исторические пути развития. Весці Беларускай дзяржаўнай акадэміі музыкі. 2019. №34. С. 107-112.

4. Иготти Е. Теория и практика интонирования в современной вокальной музыке : дисс. ... канд. иск-я : 17.00.02. Санкт-Петербург, 2011. $170 \mathrm{c}$.

5. Пэн Чэн. Китайская традиционная ладовая система и ее применение в XX веке : исследование. Москва : МПГУ, 2006.104 с.

6. Фань Юй, Кром А. Изучение и практика применения серийной техники в Китае. Проблемы музыкальной науки. 2018. № 2. С.66-73.

7. 贺思涃, 《新时期中国钢琴音乐作品创作 探析》，艺术科技，2017（30）P55. Хэ Сыюань, Хэ Сысянь. Исследование китайских фортепианных сочинений нового периода развития Китая. Искусство, науки и технологии. Ханчжоу: Чжецзянская академия сценического дизайна. 2017. № 30 (10). C.55.

8. 居其宏，《胸怀大爱的音乐诗人一 陆在易和他的声乐创作》，人民音乐，2014（11, P4-8. Цзю Цихун. Поэт и музыкант с душой, переполненной любовью. Лу Цзай-и и его вокальная музыка. Народная музыка. 2004. Вып. 11. C. $4-8$.

9. 陈燕楠, 《探求20世纪中国艺术歌曲的发 展轨迹与美学特征》, 大众文艺, 2014 （9, P 132133.Чэнь, Яньнань. Пути развития и эстетические особенности китайских художественных песен XX ст. Массовая культура. 2014. Вып. 9. С. 132-133.

10. Шули Цао. Проявление стилистических черт в китайской камерно-вокальной музыке конца XX в. Веснік Беларускага дзяржаўнага універсітэта культуры і мастацтваў. 2010. №1 (13). С.74-80.

11. 邢思敏, 《西风国学现音古韵—

罗忠镕艺术歌曲“渔家傲秋思”分析》，北方音乐，

2015 (4, Р37-38. Щин Сыминь. Анализ художественной песни «Осенние размышления» Ло Чжунжуна. Музыка Севера. 2015.Вып. 4. С. 37-38.

12. Янь Цзянань, Юнусова В. Китайская «Новая волна» и творчество Сюй Чанцзюня. Журнал Общества теории музыки. 2018. Вып. 4 (24). C.60-73.

\section{References}

1. Alkon, E. (2001) Musical thinking of the East and West, continual and discrete. Abstract of the dissertation of the doctor of art history. (17.00.02). Vladivostok [in Russian].

2. Day, Kaiyuan (2017). Vocal miniatures of Zhu Jian Era: genre and stylistic features. Problems of interaction of art, pedagogy and theory and practice. International music historical magazine. 47, 223-236 [in Russian].

3. Dongxuan, Wu. (2019). The genre of romance in the Chinese musical tradition: musical and historical ways of developmen. Vestsi Belaruskay dzyarzhaynay akademii muzyki, 34, 107-112 [in Russian].

4. Igotti, E. (2011). Theory and practice of intonation in modern vocal music. Dissertation of the candidate of art history: 17.00.02. St. Petersburg [in Russian].

5. Peng Cheng (2006). Chinese Traditional Modal System and its Application in the 20th Century: Research. |Moscow [in Russian].

6. Fan Yu, Krom A. (2018). Study and practice of using serial technology in China. Problems of Music Science, 2, 66-73. [in Russian].

7. He Siyuan, He Sixian (2017). A Study of Chinese Piano Works of the New Period of China's Development. Art, Science and Technology. Hangzhou: Zhejiang Academy of Stage Design, 30 (10), 55. [in Chinese].

8. Tszyu, Qihong (2004). Poet and musician with a soul overflowing with love. Lu Tsai-i and his vocal music. Folk music,11, 4-8. [in Chinese].

9. Chen Yannan. (2014). Ways of development and aesthetic features of Chinese art songs of the XX century. Mass culture, 9, 132-133. [in Chinese].

10. Shuli Cao (2010). The manifestation of stylistic features in the Chinese chamber vocal music of the late 20th century. Bulletin of the Belarusian State University of Culture and Arts, 1 (13), 74-80. [in Russian].

11. Shchin Symin (2015). Analysis of the art song «Autumn Reflections» by Luo Zhongrong] Music of the North, 4, 37-38 [inChinese].

12. Yan, Jianan, Yunusova, V. (2018). Chinese "New Wave" and the work of Xu Changjun. Magazine of the Society for Music Theory, 4 (24), 60-73 [in Russian].

Стаття надійшла до редакиії 10.11.2020 Отримано після доопрацювання 04.12.2020 Прийнято до друку 09.12.2020 